\title{
Radical Telomerization of Olefin with Isocyanide
}

\author{
Takeo SAegusa, Yoshihiko Ito, and Naohiko YasudA \\ Department of Synthetic Chemistry, Faculty of Engineering, \\ Kyoto University, Kyoto, Japan.
}

(Received July 17, 1970)

\begin{abstract}
Radical telomerization of olefin with isocyanide was studied. As the isocyanide telogen, $t$-butyl and benzyl isocyanides were employed. In the telomerizition of ethylene, isobutyl vinyl ether and ethyl trans-crotonate, telomers having degrees of polymerization below four as well as the isomerized product of cyanide were isolated by GLPC, and the structures of oligomers were shown to be expressed by the general formula,

$$
\mathrm{RNC}:+\mathrm{CH}_{2}=\mathrm{CHX} \underset{\mathrm{X}}{\mathrm{R}-\left(\mathrm{CH}_{2} \mathrm{CH}\right)_{\bar{n}}^{-} \mathrm{CN}}
$$

In the case of styrene, acrylonitrile, methacrylate, and 1,3-pentadiene, no low oligomer was isolated and polymers having the above general formula were produced. The chain transfer constant of $t$-butyl isocyanide in the thermal polymerization of styrene at $100^{\circ} \mathrm{C}$ was determined to be $0.33 \times 10^{-2}$. The chain transfer reaction of isocyanide was schematized on the basis of the telomer structures and the radical-reaction behavior of isocyanide.
\end{abstract}

KEY WORDS Radical Telomerization/ $t$-Butyl Isocyanide/Benzyl

Isocyanide/Chain Transfer Constant/Telogen/Imidoyl Radical/

Ethylene / Isobutyl Vinyl Ether / Ethyl Crotonate / Styrene

This paper describes the radical telomerization of olefin with isocyanide. This study is an extension of our studies on the free radical reactions of isocyanide..$^{1-3}$ The free radical reactions have been schematized by assuming the corresponding imidoyl radical (I) as the key intermediate.

$$
\begin{gathered}
\mathrm{R}-\mathrm{NC}+\mathbf{R}^{\prime} \cdot \underset{(\mathrm{I})}{\left[\mathrm{R}+\mathrm{N}=\dot{\mathrm{C}}-\mathrm{R}^{\prime}\right]} \rightarrow \\
\mathbf{R} \cdot+\mathbf{R}^{\prime} \mathrm{CN}
\end{gathered}
$$

( $\mathrm{R}=t$-butyl, benzyl)

In the radical reactions of $t$-butyl and benzyl isocyanides, the imidoyl radicals (I) derived from these isocyanides undergo $\beta$-scission, resulting in the formation of $t$-butyl and benzyl radicals, respectively. In particular, the radical isomerizations of $t$-butyl and benzyl isocyanides to the corresponding cyanides (eq 3$)^{4}$ explicitly present the characteristic reactivities of $N$-t-butyl- and $N$-benzylimidoyl radicals, as is indicated in the following scheme.

$$
\mathrm{R}-\mathrm{NC}+\mathrm{In} \cdot \underset{\mathrm{R} \cdot+\mathrm{InN}}{\longrightarrow}[\mathrm{R}-\mathrm{N}=\dot{\mathrm{C}}-\mathrm{In}] \longrightarrow
$$

(In. from a radical initiator)

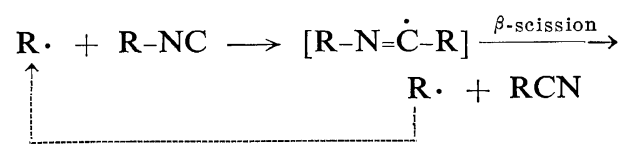

It is suggested from the above reaction scheme that $t$-butyl and benzyl isocyanides may function as a chain transfer reagent in the radical polymerization of olefin. In the present study, $t$ butyl and benzyl isocyanides have been actually found to be powerful chain transfer agents in the radical polymerization of olefins. A mixture of telomers (II) having varying degrees of polymerization was formed along with the cyanide (III) of the isomerization product.

$$
\begin{aligned}
& \begin{aligned}
\mathrm{R}-\mathrm{NC}+ & >\mathrm{C}=\mathrm{C}<\stackrel{\mathrm{In} \cdot}{\longrightarrow} \\
\mathrm{R}-(-\mathrm{C}-\mathrm{C}-\mathrm{C}-)_{n} \mathrm{CN} & +\mathrm{RCN}
\end{aligned} \\
& \text { (II) } \\
& (n=1,2,3, \cdots)
\end{aligned}
$$


Table I. Telomerization of olefin with isocyanide as telogen ${ }^{a}$

$\mathrm{R}-\mathrm{NC}+n>\mathrm{C}=\mathrm{C}<\stackrel{\mathrm{DTBP}}{\longrightarrow} \mathrm{R}-(\stackrel{\mathrm{C}}{\mathrm{C}}-\stackrel{1}{\mathrm{C}})_{\bar{n}} \mathrm{CN}$

\begin{tabular}{|c|c|c|c|c|c|c|c|c|}
\hline \multirow{2}{*}{$\begin{array}{l}\text { Isocyanide, } \\
30 \mathrm{mmol}\end{array}$} & \multirow{2}{*}{$\begin{array}{l}\text { Olefin, } \\
45 \mathrm{mmol}\end{array}$} & \multicolumn{4}{|c|}{ Yields of telomers, mmol } & \multirow{2}{*}{$\begin{array}{c}\text { Cyanide, } \\
\text { mmol }\end{array}$} & \multirow{2}{*}{$\begin{array}{c}\text { Recovered } \\
\text { isocyanide, } \\
\text { mmol }\end{array}$} & \multirow{2}{*}{$\alpha^{\mathrm{b}}$} \\
\hline & & $n=1$ & $n=2$ & $n=3$ & $n=4$ & & & \\
\hline \multirow{4}{*}{$t$-BuNC } & $\omega^{c}$ & - & - & - & - & 25.0 & 0 & \\
\hline & $\mathrm{CH}_{2}=\mathrm{CHO}$ iso $-\mathrm{Bu}$ & 6.4 & 3.6 & 2.6 & $-\mathrm{d}$ & 17.2 & 0 & \\
\hline & $\mathrm{CH}_{3} \mathrm{CH}=\mathrm{CHCO}_{2} \mathrm{Et}$ & 11.6 & 6.8 & $-d$ & $一^{d}$ & 6.4 & 2.8 & 0.7 \\
\hline & $\mathrm{CH}_{2}=\mathrm{CH}_{2} \mathrm{e}^{\mathrm{e}}$ & 17.7 & 6.3 & 2.2 & 1.1 & $-f$ & $-\mathrm{f}$ & $-f$ \\
\hline \multirow{2}{*}{$\mathrm{PhCH}_{2} \mathrm{NC}$} & $\int \quad{ }^{c}$ & 一 & - & - & - & 7.4 & 10.6 & \\
\hline & $\left\{\mathrm{CH}_{2}=\mathrm{CHO}\right.$ iso $-\mathrm{Bu}$ & 4.8 & $-\mathrm{d}$ & $-\mathrm{d}$ & $-d$ & 9.3 & 11.6 & 0.5 \\
\hline
\end{tabular}

a Conditions: Chlorobenzene, $7 \mathrm{ml}$; di-t-butyl peroxide, $3 \mathrm{mmol} ; 130^{\circ} \mathrm{C}, 24 \mathrm{hr}$ in a sealed tube.

b $\alpha$ is the ratio of $\sum_{n} \mathrm{R}-\left(\stackrel{\mathrm{C}}{\mathrm{C}}-\mathrm{C}_{1}^{\mathrm{C}}\right)_{n} \mathrm{CN} / \mathrm{RCN}$

c Isomerization reaction of isocyanide under the same conditions except for the absence of olefin.

d Not detected.

e $t$-Butyl isocyanide $50 \mathrm{mmol}$, ethylene $37 \mathrm{~atm} ., 130^{\circ} \mathrm{C}, 24 \mathrm{hr}$ in a stainless steel tube.

f Not determined.

\section{RESULTS AND DISCUSSION}

\section{Telomerization of Olefin}

The results of telomerizations of olefins with isocyanide as telogen in the presence of di-tbutyl peroxide (DTBP) are shown in Table I. Telomers having different degrees of polymerization were isolated separately by GLPC and their structures were adequately determined by NMR and IR spectra as well as by elemental analyses.

In the reactions of isobutyl vinyl ether and crotonate with $t$-butyl or benzyl isocyanide under the conditions indicated in Table $I$, a telomer mixture $(n=1-3$ in II) was obtained along with the isomerized cyanide. Higher telomers could not be detected. The reaction of ethylene with $t$-butyl isocyanide also produced a telomer mixture $(n=1-4$ in II). However, in this case the fairly high telomer, having an average molecular weight of 850 , was also isolated as a waxy solid from methanol. In the case of styrene, acrylonitrile, methacrylate and 1,3-pentadiene, only high polymers were produced, and the amount of isomerized cyanide was only minute. The IR and NMR spectra of these polymers show the presence of both $t$-butyl (or benzyl) and cyanide groups in the polymer chain.

On the basis of the consideration that $\mathrm{N}-\mathrm{t}$ butyl(or benzyl)imidoyl radical readily undergoes $\beta$-scission to produce the corresponding cyanide and $t$-butyl (or benzyl) radical, the following reaction scheme will explain the formation of the telomer as well as the side reaction of the isomerization to the corresponding cyanide.

$$
\begin{aligned}
& \mathrm{R}-\mathrm{NC}+\mathrm{In} \cdot \longrightarrow[\mathrm{R}-\mathrm{N}=\dot{\mathrm{C}}-\mathrm{In}] \longrightarrow \mathrm{R} \cdot+\mathrm{InCN} \\
& \text { (In. from radical initiator) }
\end{aligned}
$$

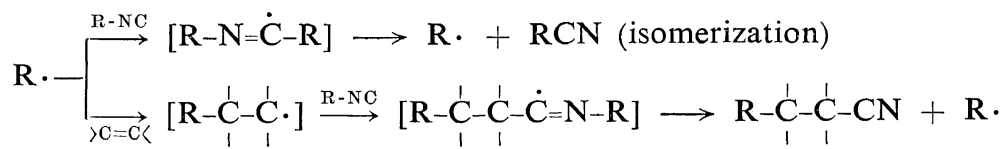

$$
\begin{aligned}
& \downarrow \downarrow \mid n>\mathbf{C}=\mathrm{C}<\quad \text { (telomerization) }
\end{aligned}
$$

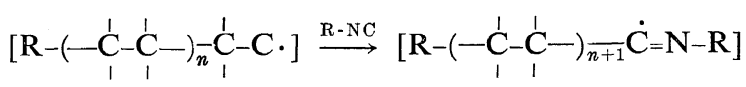

$$
\begin{aligned}
& \longrightarrow \mathrm{R}-(-\stackrel{\mathrm{I}}{\mathrm{C}}-\stackrel{\mathrm{I}}{\mathrm{C}}-)_{n+1} \mathrm{CN}+\mathrm{R} \text {. }
\end{aligned}
$$


$t$-Butyl (or benzyl) radical produced via $\beta$-scission of $N$-t -butyl(or benzyl)imidoyl radical can add to either isocyanide or olefin. Therefore, the ratio $(\alpha)$ of the total amounts of telomers (II) to that of isomerized cyanide (III) may be taken as a measure of the relative reactivity of olefin toward the $t$-butyl (or benzyl) radical. As seen in Table I (last column), it is obvious that olefin having an electron withdrawing substituent, such as crotonate, has a higher reactivity toward the $t$-butyl (or benzyl) radical. This finding is explained by both the resonance and inductive effects of the carboxylate substituent. This substituent stabilizes a neighboring radical by the resonance effect. Moreover, as the $t$-butyl (or benzyl) radical is considered to have a nucleophilic character, the electron-withdrawing group may also favor the reactivity of olefin.

Chain Transfer Constant of t-Butyl Isocyanide in the Thermal Polymerization of Styrene

$t$-Butyl isocyanide is considered to be a new type of chain transfer reagent in the radical polymerization of olefin. It is interesting to compare it with $\mathrm{CCl}_{4}$, one of the typical chain transfer reagents. In the former, chain transfer occurs throught the $\beta$-scission of the imidoyl radical formed from the reaction of the growing polymer radical with the isocyanide, while in the latter it occurs through the abstraction of an atom from $\mathrm{CCl}_{4}$ by the growing polymer radical. ${ }^{5,6}$

$$
\sim \underset{\mathrm{C}}{\mathrm{C}}+\mathrm{CCl}_{4} \stackrel{\text { Abstraction }}{\longrightarrow} \sim \mathrm{C}-\mathrm{Cl}+\mathrm{Cl}_{3} \mathrm{C} \cdot
$$

The reactivity of $t$-butyl isocyanide as a chaintransfer reagent in the thermal polymerization of styrene was examined by determining the chain transfer constant. As previously mention- ed, the polystyrene thus obtained contains both cyano and $t$-butyl groups in its polymer chain. As another possibility, a $N$-t-butylimidoyl radical formed from the reaction of the growing polystyrene radical with $t$-butyl isocyanide may attack further styrene monomers without undergoing $\beta$-scission. This reaction might ultimately lead to the formation of a copolymer which contains the imino units $\left(\begin{array}{c}-\mathrm{C}- \\ \mathrm{N}-\mathrm{Bu}-t\end{array}\right)$ in the polymer chain. However, this possibility is quite unlikely from the inspection of the reaction products. The IR spectrum of the polymer did not show any absorption of the $>\mathrm{C}=\mathbf{N}$ - bond. In addition, the absence of the isocyanide unit in the polymer was shown by the absence of a carbonyl group in the acid-treated polymer. The polymer was treated with aq $\mathrm{HCl}$ solution and then subjected to reaction with 2,4-dinitrophenylhydrazine. The formation of hydrozone was not detected. These findings indicate that the $N$-t-butylimidoyl radical intermediate formed by the reaction of the growing polymer radical with $t$-butyl isocyanide undergoes $\beta$-scission exclusively, resulting in a $t$-butyl radical which starts a new polymerization. The chain transfer constant of $t$-butyl isocyanide in the thermal $\left(100^{\circ} \mathrm{C}\right)$ polymerization of styrene was determined according to Mayo's equation ${ }^{7}$ (eq 10)

$$
\frac{1}{\bar{P}}=C \frac{[\mathrm{S}]}{[\mathrm{M}]}+\frac{1}{\bar{P}_{0}}
$$

in which $\bar{P}$ and $\bar{P}_{0}$ are the degrees of polymerization of the styrene polymers formed in the presence and absence of $t$-butyl isocyanide, respectively, and $[\mathrm{S}]$ and $[\mathrm{M}]$ are the concentrations of $t$-butyl isocyanide and the styrene monomer, respectively.

The conversions $\%$ of the styrene polymeri-

Table II. Thermal polymerization of styrene in $t$-butyl isocyanide ${ }^{a}$

\begin{tabular}{cccccc}
\hline$\frac{[t \text {-BuNC }]}{[\text { Styrene }]}=\left(\frac{[\mathrm{M}]}{[\mathrm{S}]}\right)$ & Yield, \% & {$[\eta], 100 \mathrm{ml} / \mathrm{g}$} & $M \times 10^{-4}$ & $\bar{P}$ & $(1 / \bar{P}) \times 10^{4}$ \\
\hline 0.000 & 9.98 & 1.77 & 36.8 & 3538 & 2.83 \\
0.101 & 9.39 & 1.15 & 21.8 & 2.096 & 4.77 \\
0.202 & 8.11 & 0.60 & 9.7 & 929 & 10.76 \\
0.288 & 6.73 & 0.53 & 8.3 & 797 & 12.55 \\
0.416 & 5.83 & 0.42 & 6.2 & 588 & 16.72 \\
\hline
\end{tabular}

a Reaction conditions: $100^{\circ} \mathrm{C}, 4.5 \mathrm{hr}$.

Polymer J., Vol. 1, No. 5, 1970 
zation were below 10\%. The average molecular weight was calculated from viscosity measurement according to the equation ${ }^{8}$

$$
[\eta]=0.55 \times 10^{-4} M^{0.81}
$$

in which $[\eta]$ is intrinsic viscosity in $\mathrm{d} l / \mathrm{g}$, and $M$ is the number-average molecular weight. The results obtained are given in Table II. The chain transfer constant $(C)$ in eq 10 ) was determined to be $0.33 \times 10^{-2}$ from the slope of a straight line of the plot of $1 / \bar{P} v s . \quad[\mathrm{S}] /[\mathrm{M}]$

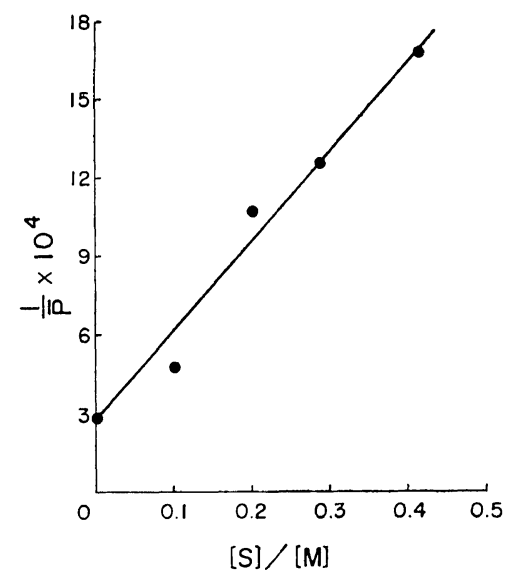

Figure 1. The plots of $1 / P \bar{v}$. $[\mathrm{S}] /[\mathrm{M}]$ (data from Table II).

(Figure 1). This value indicates the high reactivity of $t$-butyl isocyanide towards a free radical.

\section{EXPERIMENTAL}

\section{Reagents}

Olefinic compounds were commercial reagents, which were purified by the usual procedures and distilled under nitrogen before use. Styrene was purified in the following way: commercial styrene monomer was washed successively with sodium thiosulfate aq solution, water, sodium hydroxide aq solution and water, dried over barium oxide, and finally distilled under nitrogen. Isocyanides were prepared according to Ugi's procedure ${ }^{9}$ and purified by distillation using a spinning band column under nitrogen.

\section{General Procedure of Telomerization}

A mixture of $30 \mathrm{mmol}$ of isocyanide, $45 \mathrm{mmol}$ of olefinic monomer, $7 \mathrm{~m} l$ of chlorobenzene (as a solvent) and $3 \mathrm{mmol}$ of di-t-butyl peroxide (DTBP) was heated under nitrogen in a sealed tube at $130^{\circ} \mathrm{C}$ in an oil bath for $24 \mathrm{hr}$. The telomerization of ethylene was carried out in a stainless-steel microautoclave. After the reaction, the reaction mixture was subjected to fractional distillation, and the distillate was analyzed by GLPC. Each fraction was isolated by preparative GLPC. The structures of the products were examined by IR and NMR spectra and elemental analysis.

Telomers from Reaction of Isobutyl Vinyl Ether and t-Butyl Isocyanide

$\left(\mathrm{CH}_{3}\right)_{3} \mathrm{CCH}_{2} \mathrm{CHCN}$ : Bp $87^{\circ} \mathrm{C}(10 \mathrm{~mm}) ; \mathrm{IR}$ $\mathrm{OCH}_{2} \mathrm{CH}\left(\mathrm{CH}_{3}\right)_{2}$

(neat) $2280 \mathrm{~cm}^{-1}$ (very weak, $\nu_{\mathrm{C} \equiv N}$ ); NMR

$\left(\mathrm{CDCl}_{3}\right), \quad \delta 4.10$ (triplet, $\left.1 \mathrm{H}, \quad{ }^{\prime}{ }^{\prime} \mathrm{HCN}\right), 3.35$ (multiplet, $2 \mathrm{H},-\mathrm{OCH}_{2} \mathrm{CH}-$ ), $1.5-\overline{2.2}$ (multiplet, $3 \mathrm{H},-\mathrm{OCH}_{2} \mathrm{CH}\left(\mathrm{CH}_{3}\right)_{2}$ and $\left.\left(\mathrm{CH}_{3}\right)_{3} \mathrm{CCH}_{2} \mathrm{CH}-\right), 1.00$ (singlet, $9 \mathrm{H},\left(\mathrm{CH}_{3}\right)_{3} \mathrm{C}-$ ) and $0.95 \overline{\mathrm{ppm}}$ (doublet, $\left.6 \mathrm{H},-\mathrm{CH}_{2} \mathrm{CH}\left(\mathrm{CH}_{3}\right)_{2}\right)$

Anal. Calcd for $\mathrm{C}_{11} \mathrm{H}_{21} \mathrm{ON} ; \mathrm{C}, 72.08 ; \mathrm{H}$, 11.55; N, 7.64. Found: C, 72.14; H, 11.36; N, 7.55 .

$$
\begin{gathered}
\left(\mathrm{CH}_{3}\right)_{3}-\left(-\mathrm{CH}_{2} \mathrm{CH}-\right)_{2} \mathrm{CN}: \text { It was isolated } \\
\text { Oे } \mathrm{OH}_{2} \mathrm{CH}\left(\mathrm{CH}_{3}\right)_{2}
\end{gathered}
$$

by the preparative GLPC from the fraction of bp $100-120^{\circ} \mathrm{C}(3.5 \mathrm{~mm})$; IR (neat) $2280 \mathrm{~cm}^{-1}$ (very weak, $\left.\nu_{\mathrm{C} \equiv \mathrm{N}}\right)$; NMR $\left(\mathrm{CDCl}_{3}\right), \delta 4.25$ (triplet, $1 \mathrm{H},-\mathrm{CH}(\mathrm{CN}) \mathrm{O}-$ ), 2.9-3.8 (multiplet, $5 \mathrm{H}$, $-\mathrm{CH}_{2} \mathrm{CHO} \mathrm{CH}_{2}$ - and $\left.-\mathrm{CH}(\mathrm{CN}) \mathrm{OCH}_{2}-\right), 1.2-2.2$ (multiplet, $\overline{6 \mathrm{H}},\left(\mathrm{CH}_{3}\right)_{3} \mathrm{CCH}_{2}-, 2 \times-\overline{\mathrm{OCH}}{ }_{2} \mathrm{CH}\left(\mathrm{CH}_{3}\right)_{2}$ and $-\mathrm{CHCH}_{2} \mathrm{CH}(\mathrm{CN}) \mathrm{O}-$ ), and $0.8-1.1 \mathrm{ppm}$ (multiplet, $21 \mathrm{H},\left(\mathrm{CH}_{3}\right)_{3} \mathrm{CCH}_{2}-$ and $\left.2 \times-\mathrm{OCH}_{2} \mathrm{CH}\left(\mathrm{CH}_{3}\right)_{2}\right)$.

Anal. Calcd for $\mathrm{C}_{17} \mathrm{H}_{33} \mathrm{O}_{2} \mathrm{~N}$ : C, 72.04; $\mathrm{H}, 11.74$; $\mathrm{N}, 4.94$. Found: $\mathrm{C}, 72.17 ; \mathrm{H}, 11.97 ; \mathrm{N}, 4.81$.

$$
\begin{gathered}
\left(\mathrm{CH}_{3}\right)_{3} \mathrm{C}-\left(-\mathrm{CH}_{2} \mathrm{CH}-\right)_{3} \mathrm{CN} \\
\text { OCCH }_{2} \mathrm{CH}\left(\mathrm{CH}_{3}\right)_{2}
\end{gathered}
$$

ed by the preparative GLPC from the fraction of bp $140-164^{\circ} \mathrm{C}(3.5 \mathrm{~mm})$; IR (neat), $2280 \mathrm{~cm}^{-1}$ (very weak, $\nu_{\mathrm{C} \equiv N}$ ); NMR spectrum is very similar to that of the $1: 2$ telomer $(n=2)$.

Anal. Calcd for $\mathrm{C}_{23} \mathrm{H}_{45} \mathrm{O}_{3} \mathrm{~N}: \mathrm{C}, 72.01 ; \mathrm{H}$, 11.82; N, 3.65. Found: C, 72.24; H, 12.03; N, 3.45 .

Telomers from Reaction of Ethyl trans-Crotonate with t-Butyl Isocyanide

$\left(\mathrm{CH}_{3}\right)_{3} \mathrm{CCH}\left(\mathrm{CH}_{3}\right) \mathrm{CH}(\mathrm{CN}) \mathrm{CO}_{2} \mathrm{C}_{2} \mathrm{H}_{5}:$ Bp $104^{\circ} \mathrm{C}$ 
$(9.5 \mathrm{~mm}):$ IR (neat) $2280\left(\right.$ weak, $\left.\nu_{\mathrm{C} \equiv \mathrm{N}}\right)$ and 1750 $\mathrm{cm}^{-1}$ (strong, $\nu_{\mathrm{C}=0}$ ); NMR $\delta 4.35$ (quartet, $2 \mathrm{H}$, $-\mathrm{CO}_{2} \mathrm{CH}_{2} \mathrm{CH}_{3}$ ), 3.75 (doublet, $J=3 \mathrm{~Hz}, 1 \mathrm{H}$, $-\mathrm{CH}(\mathrm{CN}) \mathrm{CO}-), 2.1$ (multiplet, $1 \mathrm{H},-{ }^{\prime} \mathrm{CHCH}(\mathrm{CN})-$ ), $\overline{1.35}$ (triplet, $3 \mathrm{H},-\mathrm{CO}_{2} \mathrm{CH}_{2} \mathrm{CH}_{3}$ ), $\overline{1.15}$ (doublet, $3 \mathrm{H},\left(\mathrm{CH}_{3}\right)_{3} \mathrm{CH}\left(\mathrm{CH}_{3}\right)-$ ) and $1.05 \mathrm{ppm}$ (singlet, $9 \mathrm{H}$, $\left.\left(\mathrm{CH}_{3}\right) \mathrm{C}-\right)$.

Anal. Calcd for $\mathrm{C}_{11} \mathrm{H}_{19} \mathrm{O}_{2} \mathrm{~N}$ : C, 66.97; H, 9.71; $\mathrm{N}, 7.10$. Found: C, 67.05; H, 9.74; N, 7.36.

$\left(\mathrm{CH}_{3}\right)_{3} \mathrm{C}-(\mathrm{CH}-\mathrm{CH}-)_{2} \mathrm{CN}$ : It was isolated $\stackrel{\text { ' }}{\mathrm{C}} \mathrm{H}_{3} \mathrm{CO}_{2} \mathrm{CH}_{2} \mathrm{CH}_{3}$

by the preparative GLPC from the fraction of bp $100-128^{\circ} \mathrm{C}(3.5 \mathrm{~mm})$; IR (neat), 2280 (weak, $\left.\nu_{\mathrm{C} \equiv \mathrm{N}}\right)$ and $1730 \mathrm{~cm}^{-1}$ (strong, $\left.\nu_{\mathrm{C}=\mathrm{o}}\right) ; \mathrm{NMR}\left(\mathrm{CDCl}_{3}\right)$ $\delta \quad 4.25$ (multiplet, $4 \mathrm{H}, 2 \times-\mathrm{CO}_{2} \mathrm{CH}_{2} \mathrm{CH}_{3}$ ), 3.8 (broad singlet, $1 \mathrm{H}, \quad-\mathrm{CHCNCO}-$ ), $2.5-2.0$ (multiplet, 2H, $-\mathrm{CH}-\stackrel{+}{\mathrm{C}} \mathrm{H}\left(\mathrm{CO}_{2} \mathrm{C}_{2} \mathrm{H}_{5}\right) \mathrm{CH}-$ and $\mathrm{CH}_{3} \stackrel{\mathrm{CHCH}}{\mathrm{C}}(\mathrm{CN})-$ ), and $1.6-0.8$ ppm (multiplet, $22 \mathrm{H},\left(\mathrm{CH}_{3}\right)_{3} \mathrm{C}-,\left(\mathrm{CH}_{3}\right)_{3} \mathrm{CCH}\left(\mathrm{CH}_{3}\right)-,-{ }^{\prime} \mathrm{CHCH}\left(\mathrm{CH}_{3}\right)-$ ' $\mathrm{CH}-$ and $\left.2 \times \mathrm{CO}_{2} \mathrm{CH}_{2} \mathrm{CH}_{3}\right)$.

Anal. Calcd for $\overline{\mathrm{C}}_{17} \mathrm{H}_{29} \mathrm{O}_{4} \mathrm{~N}: \mathrm{C}, 65.56 ; \mathrm{H}$, 9.39; N, 4.50. Found: C, 65.28; H, 9.61; N, 4.58 .

Telomerization of Ethylene with $t$-Butyl Isocyanide

Into a microautoclave $(50 \mathrm{ml})$ containing 50 mmol of $t$-butyl isocyanide and $5 \mathrm{mmol}$ of DTBP, ethylene was charged to $35 \mathrm{~kg} / \mathrm{cm}^{2}$. The microautoclave was heated at $130^{\circ} \mathrm{C}$ for 24 hours, and then the reaction mixture was subjected to distillation.

$\left(\mathrm{CH}_{3}\right)_{3} \mathrm{CCH}_{2} \mathrm{CH}_{2} \mathrm{CN}$ : It was isolated by the preparative GLPC from the fraction of bp 70$79^{\circ} \mathrm{C}\left(9 \mathrm{~mm}\right.$ ); IR (neat) $2270 \mathrm{~cm}^{-1}$ (weak, $\nu_{\mathrm{C} \equiv \mathrm{N}}$ ); NMR $\left(\mathrm{CDCl}_{3}\right) \quad \delta \quad 2.1-2.5$ (multiplet, $2 \mathrm{H}$, $-\mathrm{CH}_{2} \mathrm{CN}$ ), $1.4-1.8$ (multiplet, $2 \mathrm{H},-\mathrm{CH}_{2} \mathrm{CH}_{2} \mathrm{CN}$ ), and 0.95 (singlet, $9 \mathrm{H},\left(\mathrm{CH}_{3}\right)_{3} \mathrm{C}-$ ).

Anal. Calcd for $\mathrm{C}_{7} \mathrm{H}_{13} \mathrm{~N}$ : C, 75.61; H, 11.79; $\mathrm{N}, 12.60$. Found: C, 75.88; H, 11.55; N, 12.82.

$\left(\mathrm{CH}_{3}\right)_{3} \mathrm{C}-\left(-\mathrm{CH}_{2} \mathrm{CH}_{2}-\right)_{2} \mathrm{CN}$ : It was isolated by the preparative GLPC from the fraction of bp $90-120^{\circ} \mathrm{C}(9 \mathrm{~mm})$; (neat) $2270 \mathrm{~cm}^{-1}$ (weak, $\nu_{\mathrm{C} \equiv \mathrm{N}}$ ); $\mathrm{NMR}\left(\mathrm{CDCl}_{3}\right) \delta 2.35$ (triplet, $2 \mathrm{H},-\mathrm{CH}_{2} \mathrm{CH}_{2} \mathrm{CN}$ ), 1.8-1.1 (multiplet, $6 \mathrm{H},\left(\mathrm{CH}_{3}\right)_{3} \mathrm{CH}_{2} \mathrm{CH}_{2} \mathrm{CH}_{2} \mathrm{CH}_{2}$ ), and $0.90 \mathrm{ppm}$ (singlet, $9 \mathrm{H},\left(\overline{\mathrm{CH}}_{3}\right)_{3} \mathrm{C}-$ ).

Anal. Calcd for $\mathrm{C}_{9} \mathrm{H}_{17} \mathrm{~N}$ : $\mathrm{C}, 77.63 ; \mathrm{H}, 12.31$; $\mathrm{N}, 10.06$. Found: C, 77.40; H, 12.55; N, 9.93. $\left(\mathrm{CH}_{3}\right)_{3} \mathrm{C}-\left(-\mathrm{CH}_{2} \mathrm{CH}_{2}-\right)_{3} \mathrm{CN}$ : It was isolated by the preparative GLPC from the fraction of bp $100-130^{\circ} \mathrm{C}(3 \mathrm{~mm})$; IR (neat) $2270 \mathrm{~cm}^{-1}$ (weak, $\left.\nu_{\mathrm{C} \equiv \mathrm{N}}\right)$; NMR (CDCl) $\delta 2.35$ (triplet, $2 \mathrm{H}$, $-\mathrm{CH}_{2} \mathrm{CH}_{2} \mathrm{CN}$ ), 1.8-1.1 (multiplet, $10 \mathrm{H},\left(\mathrm{CH}_{3}\right)_{3}-$ (- $\left.\mathrm{CH}_{2} \overline{\mathrm{CH}}_{2}-\right)_{2} \mathrm{CH}_{2} \mathrm{CH}_{2}-$ ), and $0.90 \mathrm{ppm}$ (singlet, $\left.9 \mathrm{H},\left(\mathrm{CH}_{3}\right)_{3} \mathrm{C}-\right)$.

Anal. Calcd for $\mathrm{C}_{11} \mathrm{H}_{21} \mathrm{~N}: \mathrm{C}, 78.97 ; \mathrm{H}, 12.65$; $\mathrm{N}, 8.37$. Found: $\mathrm{C}, 78.70 ; \mathrm{H}, 12.82 ; \mathrm{N}, 8.43$.

$\left(\mathrm{CH}_{3}\right)_{3} \mathrm{C}-\left(-\mathrm{CH}_{2} \mathrm{CH}_{2}-\right)_{4} \mathrm{CN}$ : It was isolated from the fraction of bp $140-148^{\circ} \mathrm{C}(3 \mathrm{~mm})$ IR (neat) $2260 \mathrm{~cm}^{-1}$ (weak, $\nu_{\mathrm{C} \equiv \mathrm{N}}$ ); NMR $\left(\mathrm{CDCl}_{3}\right) \delta$ $2.30 \mathrm{ppm}$ (triplet, $2 \mathrm{H},-\mathrm{CH}_{2} \mathrm{CH}_{2} \mathrm{CN}$ ), $1.8-1.1$ (multiplet, 14, $\left(\mathrm{CH}_{3}\right) \mathrm{C}-\left(-\mathrm{CH}_{2} \overline{\mathrm{CH}}_{2}-\right)_{3}-\mathrm{CH}_{2} \mathrm{CH}_{2}-$ ), and $0.85 \mathrm{ppm}$ (singlet, $9 \mathrm{H},\left(\mathrm{CH}_{3}\right)_{3} \mathrm{C}-$ ).

Anal. Calcd for $\mathrm{C}_{13} \mathrm{H}_{25} \mathrm{~N}: \mathrm{C}, 79.93 ; \mathrm{H}, 12.90$; $\mathrm{N}, 7.17$. Found: C, 80.22; H, 12.83; N, 7.01. Telomers from Reaction of Isobutyl Vinyl Ether with Benzyl Isocyanide

$\mathrm{C}_{6} \mathrm{H}_{5} \mathrm{CH}_{2} \mathrm{CH}_{2} \mathrm{CH}(\mathrm{CN}) \mathrm{OCH}_{2} \mathrm{CH}\left(\mathrm{CH}_{3}\right)_{2}: \mathrm{Bp} 109$ $111^{\circ} \mathrm{C}(1 \mathrm{~mm})$; IR (neat) $2240 \mathrm{~cm}^{-1}$ (very weak, $\left.\nu_{\mathrm{C} \equiv \mathrm{N}}\right) ; \mathrm{NMR}\left(\mathrm{CDCl}_{3}\right) \delta 7.25 \mathrm{ppm}$ (singlet, $5 \mathrm{H}$, $\mathrm{C}_{6} \mathrm{H}_{5} \mathrm{CH}_{2^{-}}$), 4.05 (triplet, $1 \mathrm{H},-\mathrm{CH}(\mathrm{CN}) \mathrm{O}_{-}$), 3.35 (multiplet, $2 \mathrm{H},-\mathrm{OCH}_{2} \mathrm{CH}-$ ), 2.85 (triplet, $2 \mathrm{H}$, $\mathrm{C}_{6} \mathrm{H}_{5} \mathrm{CH}_{2} \mathrm{CH}_{2}$ ), 2.4-1.6 (multiplet, $3 \mathrm{H}$, $\mathrm{C}_{6} \mathrm{H}_{5} \overline{\mathrm{CH}}_{2} \mathrm{CH}_{2} \mathrm{CH}-$ ) and $\left.\mathrm{OCH}_{2} \mathrm{CH}\left(\mathrm{CH}_{3}\right)_{2}\right)$, and 0.95 ppm (doublet, $6 \mathrm{H},-\mathrm{CH}\left(\mathrm{CH}_{3}\right)_{2}$ ).

Anal. Calcd for $\mathrm{C}_{14} \overline{\mathrm{H}_{19} \mathrm{NO}} \mathrm{C}, 77.38 ; \mathrm{H}$, $8.81 ; \mathrm{N}, 6.45$. Found: C, 77.15; H, 8.99; N, 6.49 .

Chain Transfer Constant of t-Butyl Isocyanide in the Styrene Polymerization.

Preparation of Polystyrene Sample

The reaction of styrene with $t$-butyl isocyanide was carried out under nitrogen in a glass tube. Weighed amounts of styrene $(50-75 \mathrm{mmol})$ and $t$-butyl isocyanide $(5-30 \mathrm{mmol})$ were placed in the tube, and the tube was attached to a vacuum line. The tube was cooled by liquid nitrogen to freeze the contents, and then evacuated. This proceeure was repeated three times. The tube was then sealed and dipped into an oil bath maintained at $100 \pm 0.1^{\circ} \mathrm{C}$. After $5 \mathrm{hr}$ (in order to hold to about $10 \%$ conversion), the reaction mixture was dissolved in benzene $70 \mathrm{~m} l$ and then the solution was frozen in Dry Ice and subjected to sublimation under reduced pressure to remove the remaining $t$-butyl isocyanide and styrene monomer together with benzene. The obtained solid was purified repeatedly by the benzene 
freeze-drying method. Finally, the polystyrene thus obtained was dried in vacuo until constant weight was achieved.

Determination of Molecular Weight from Viscosity

Solution viscosity was determined in toluene at $30^{\circ} \mathrm{C}$ using an Ubbelohde viscometer. The intrinsic viscosity, $[\eta]$, was obtained from specific viscosities at three polymer concentrations.

\section{REFERENCES}

1. T. Saegusa, S. Kobayashi, Y. Ito, and N. Yasuda, J. Amer. Chem. Soc., 90, 4182 (1968).
2. T. Saegusa, S. Kobayashi, and Y. Ito, J. Org. Chem., 35, 2118 (1970).

3. T. Saegusa, Y. Ito, N. Yasuda, and T. Hodaka, J. Org. Chem. in press.

4. T. Saegusa, Y. Ito, and N. Yasuda, unpublished.

5. R. A. Gregg and F. R. Mayo, J. Amer. Chem. Soc., 70, 2373 (1948).

6. S. L. Kapur, J. Polym. Sci., 11, 399 (1956).

7. F. R. Mayo, J. Amer. Chem. Soc., 65, 2324 (1943).

8. T. Alfrey, A. Bartovics, and H. Mark, J. Amer. Soc., 65, 2319 (1943).

9. I. Ugi and R. Meyr, Chem. Ber., 93, 239 (1969). 